\title{
The scale epithelium as a novel, non-invasive tool for environmental assessment in fish: Testing exposure to linear alkylbenzene sulfonate
}

\author{
R.M.S. Alves ${ }^{\text {a }}$, B.F. Pereira ${ }^{\text {b,* }}$, R.G.L.G. Ribeiro ${ }^{\text {c }}$, D.L. Pitol ${ }^{\mathrm{d}}$, C.M Ciamarro ${ }^{\mathrm{a}}$, J.R.T. Valim ${ }^{\text {a }}$, \\ F.H. Caetano ${ }^{\text {a }}$ \\ a Universidade Estadual Paulista "Júlio de Mesquita Filho" - UNESP, Campus of Rio Claro, Instituto de Biociências, SP, Brazil \\ ${ }^{\mathrm{b}}$ Universidade Federal do Oeste da Bahia - UFOB, Centro de Ciências Biológicas e da Saúde, Campus of Barreiras, BA, Brazil \\ ' Universidade de Coimbra, Faculdade de Ciências e Tecnologia, Departamento de Ciências da Vida, Coimbra, Portugal \\ ${ }^{\mathrm{d}}$ Faculdade de Odontologia de Ribeirão Preto, Universidade de São Paulo, FORP/USP, Campus of Ribeirão Preto, SP, Brazil
}

\section{A R T I C L E I N F O}

\section{Article history:}

Received 7 August 2015

Received in revised form

27 February 2016

Accepted 7 March 2016

Available online 15 March 2016

Keywords:

Prochilodus

Scale

Skin

LAS

Gill

Non-invasive

\begin{abstract}
A B S T R A C T
Increasing pollution levels have turned our attention to assessing lethal and sublethal effects of toxic agents using the most informative techniques possible. We must seek non-invasive or non-lethal sampling methods that represent an attractive alternative to traditional techniques of environmental assessment in fish. Detergents are amongst the most common contaminants of water bodies, and LAS (Linear Alkylbenzene Sulfonate) is one of the most used anionic surfactant on the market. Our study analyzed morphological alterations (histological and histochemical) of the scale epithelium of Prochilodus lineatus under exposure to two concentrations of LAS, $3.6 \mathrm{mg} / \mathrm{L}$ and $0.36 \mathrm{mg} / \mathrm{L}$, for a period of 30 days and evaluated at 14, 21 and 30 days. In order to establish morphological analysis of the scale epithelium as a new non-lethal environmental assessment tool that is reliable and comparable to classic methods, the relative sensibility of this technique was compared to a commonly used method of environmental assessment in fish, the estimation of the effects of pollutants upon branchial morphology. Two experiments were carried out, testing animals in tanks, and in individual aquariums. Results of analyses on gill tissue show that exposure to $3.6 \mathrm{mg} / \mathrm{L}$ of surfactant caused severe damage, including hyperplasia, hypertrophy and fusion at 14 days, with aneurisms at 21 and 30 days; while exposure to $0.36 \mathrm{mg} / \mathrm{L}$ had lighter effects on the organ, mainly lower incidence of fusion and hyperplasia. Aditionally, scale morphology was altered severely in response to $3.6 \mathrm{mg} / \mathrm{L}$ of LAS, consistently showing increased mucous and club cell production. Epithelial thickness was the most variable parameter measured. Scale epithelium sensibility has the potential to be a reliable environmental marker for fish species since it has the advantage of being less invasive when compared to traditional methods. However, more studies are required to increase the robustness of the technique before it can be generally applied.
\end{abstract}

(c) 2016 Elsevier Inc. All rights reserved.

\section{Introduction}

There is a growing sense of urgency regarding global pollution which drives the need to develop the most informative diagnostic techniques to assess lethal and sub-lethal effects of water contaminants (Anderson et al., 1994) and search for non-invasive or non-lethal sampling techniques that represent an attractive alternative to traditional monitoring methods in fish (Heltsley et al., 2005). In many developing countries water quality is assessed primarily through physical and chemical criteria, with little information concerning effects of several types of contaminants (Camargo and Martinez, 2007).

\footnotetext{
* Corresponding author.

E-mail address: brunofp22@hotmail.com (B.F. Pereira).
}

Morphological analysis is a common, efficient tool for identifying the effects of contaminants on target-organs through the evaluation of lesions and adaptive changes (Schwaiger et al., 1997) and fish scales have long been used for such purpose in bioaccumulation studies (e.g.: Abdullah et al. (1976), Burguer et al. (2013), Dua and Gupta (2005)). Several authors also explore the potential of epithelial tissues as pollution indicators in fish, measuring mucous production and epithelium thickness (Dowling and Mothersill, 2001; Kilemade and Mothersill, 2000; Pretti et al., 2008; Rajan and Banerjee, 1991). Whereas other studies/authors show that alternative structures in the epithelial tissue can be evaluated. For example, club cells, which are unicellular epidermal glands characteristic of several orders of fish responsible for the production of pheromones in response to toxic and stress agents (Brown, 2003; Chivers et al., 2007; Zaccone et al., 2001). Their abundance has been associated with the occurrence of mechanical 
damage to the skin (Chivers et al., 2007). Yet, no attempts have been made to use fish scales as a non-invasive method to obtain samples of epithelial tissue for morphological analysis.

Gills are considered the target-organs of several types of contaminants and changes in its structure are largely used for contamination assessment (Mallatt, 1985), which makes them a reliable standard to validate the sensibility of the scale epithelium as an environmental assessment technique.

Detergents represent a great portion of the most common aquatic contaminants and linear alkylbenzene sulfonates (LAS) are one of the major anionic surfactants used in detergents on the market (Hera, 2009). The toxic effects of LAS in different concentrations and its persistence in several types of water and effluents have been extensively studied (Konnecker et al., 2011; Mungray and Kumar, 2009). Data on aquatic toxicity of LAS is rich and has been compiled by the International Association for Soaps, Detergents and Maintenance Products and the European Chemical Industry Council. Toxic levels for many species have been recorded in European studies -0.25 up to $4.1 \mathrm{mg} / \mathrm{L}$ in chronic exposure, with Predicted no effect concentration (PNEC) of $0.27 \mathrm{mg} / \mathrm{L}$ (Hera, 2009). However, neotropical regions have significantly fewer studies on the matter, which makes it an important aquatic toxicant that needs to be evaluated for neotropical environments.

Only a few neotropical fish species can be used as models in environmental assessment, one of them is Prochilodus lineatus, a specie commonly used in toxicity studies (e.g.: Cerqueira and Fernandes (2002), Palermo et al. (2015), Paulino et al. (2012), Pereira et al. (2012, 2014) and Simonato et al. (2008)). It is abundant in South American basins (Reis et al., 2003) and is present in rivers that continuously receive surfactant contaminants from domestic and industrial dejects (Meschiatti and Arcifa, 2009). Therefore, it represents a solid neotropical bioindicator for environmental monitoring.

Our research aimed to investigate the use of morphological analysis of the scale epithelium as a reliable tool for environmental assessment in fish by testing the effects of a common aquatic contaminant on the number of specialized cells (club cells and mucous cells) and thickness of the epithelium of a well-known neotropical specie - P. lineatus. Additionally, a comparison was made of this new technique to effects on gill morphology, a well established technique in toxicity studies.

\section{Material and methods}

\subsection{Experiments and sampling}

Two experiments were carried out, one in $310 \mathrm{~L}$ tanks containing 24 animals, and one in $25 \mathrm{~L}$ individual aquariums. Tank experiments were designed to sample fish for morphological analyses of gills and scales and aquarium experiments were designed to sample fish for scales and food consumption. Tank experiments only would originally suffice for morphological analyses, but the aquarium experiments were designed as another set of tests to obtain feeding data that will not be discussed in this paper. Because the experimental design in aquariums allowed for individual responses to be properly accompanied, we present scale results of those tests in this paper, although we do not present the feeding results.

For the tank experiments, 72 juveniles with $7-10 \mathrm{~cm}$ body length and approximately $10 \mathrm{~g}$ were obtained on a pisciculture (Piscicultura Polettini - Mogi-Mirim, SP, Brazil), divided into three groups of 24 individuals (control, first concentration of LAS and second concentration) and acclimatized for two weeks prior to the beginning of experiments in $310 \mathrm{~L}$ polyethylene tanks equipped with UV filters, mechanical filters, heaters, water pumps and sandy bottoms. The sand was acquired at a local store and consisted of clean, white sand, which was replaced by new, clean sand before the start of every repetition. The same was done with mechanical filters.

Fish densities per tank were not expected to affect fish growth, since the densities in our study are not high if compared with previous studies which indicate that no effects on growth are observed in densities up to 0.5 fish/L for much bigger juveniles (24.9 g).

One experimental group (lower concentration) was exposed to a $0.36 \mathrm{mg} / \mathrm{L}$ dilution of LAS (Sigma-Aldrich@-code 289957), a second group, to a dilution of $3.6 \mathrm{mg} / \mathrm{L}$ and the third was a control group (control), exposed to water from a well available on campus (UNESP Rio Claro - Rio Claro, SP, Brazil). Water quality for all experimental groups can be verified in a physical and chemical characterization available on the original research (Alves, 2015) and details of the methods for collection and measuring physical and chemical parameters are given on a subsequent topic. LAS concentrations were chosen based on Mungray and Kumar (2009), that showed that surfactant concentrations vary from 0.36 to $0.49 \mathrm{mg} / \mathrm{L}$ in rivers that receive effluents of sewage treatment plants, and $3.6-4.9 \mathrm{mg} / \mathrm{L}$ in effluents directly from sewage treatment plants. Detergent dilutions were made with the same water used in the control groups.

Three sampling periods were executed on days 14, 21 and 30, in order to detect structural changes provoked by low concentrations during prolonged exposure, similarly to experimental designs from other authors (Hera, 2009). The experiment was conducted twice, animals were fed neotropical fish food (Poytara Disco@) which fulfils quality levels of 35\% Crude Protein set for animal food and underwent $48 \mathrm{~h}$ fasting before every sampling. In every sampling period, eight scales per individual were removed from eight individuals per group using tweezers. They were always removed from the posterior half of the body, near the caudal fin and under the lateral line, due to the fact that juveniles do not shed many scales and even in adult specimens loss is higher above the lateral line (McCart, 1967). Additionally, a selection was made for six of the same animals already sampled for scales in the tank experiments in each group and in every sampling group, to be sampled for gills. Two gill arches were removed from the operculum opening of each of the aforementioned fish. Extraction of gills was performed under anesthesia using a benzocaine solution $(0.1 \mathrm{~g}$ of benzocaine per milliliter of ethyl alcohol in every $100 \mathrm{~mL}$ of deionized water), following approval by the Ethics Committee (Comissão de Ética no Uso de Animais - CEUA - UNESP, campus of Rio Claro - Rio Claro, SP, Brazil, Process no. 031/2012).

For aquarium experiments, 12 juveniles were distributed amongst $1225 \mathrm{~L}$ glass aquaria (1 individual/aquarium) and acclimatized for two weeks prior to the beginning of every experiment. Aquariums were equipped with UV filters, mechanical filters, heaters and water pumps. Animals were assigned to 3 groups, each comprising of 4 aquariums. LAS concentrations and sampling periods were the same as in tank experiments. Individuals were fed neotropical fish food of different granulation (Tetra Veggie algae wafer( $)$ ), and underwent $24 \mathrm{~h}$ fasting before sampling took place. Fasting periods were different in an effort to minimize confinement stress, as the target specie swims in shoals. Food with a different granulation was used because the experimental design for aquarium tests was originally outlined to assess food intake which can only be done with a special kind of granulation.

The experiment in aquariums was repeated four times to match sample sizes between both types of experiment. Sampling procedures were similar to the previously mentioned, except that animals were not sacrificed for gill collection during the experiments and the area where scales were removed was treated with iodine to avoid infections and help the regeneration process. 


\subsection{Scale epithelium}

Samples from both experiments were fixed with aqueous Bouin and $10 \%$ formaldehyde, decalcified in 10\% EDTA, dehydrated in ethyl alcohol and embedded in historesin Leica@. Histological slides were submitted to H.E. (hematoxylin-eosin) and PAS (Periodic Acid-Schiff) techniques according to Paulete and Beçak (1976), and mounted in Entellan@. Eight longitudinal sections of eight scales per individual were made. Total cell count was estimated for mucous cells in PAS slides and for club cells, in H.E. slides, on the whole length of the scale epithelium. Mucous cells were selected as a proxy for the status of the immune system, since they constitute the first line of defense against pollutants (Coello and Khan, 1996); while club cells were selected due to their recent association to pathogen presence and mechanical lesions in fish skin (Chivers et al., 2007).

Epithelium thickness was measured in H.E. slides, as variations in skin thickness are a common response to contaminants (e.g. Dowling and Mothersill (2001)). Thickness in five equidistant points in the scale epithelium were measured using ImageJ@ in a new methodology we now propose. These five points represent 0 , $0.25,0.5,0.75$ and 1.0 of the whole length of the epithelium including extremities. The whole length of the scale and of the epithelium were also measured (Fig. 1). As epithelial thickness was not stable along the five points measured, it was compared between the two concentrations of LAS on a point by point manner using the Friedman/Dunn test for repeated measures after the Shapiro-Wilk's normality test. Cell counts were also submitted to Shapiro-Wilk's normality test and Friedman/Dunn test for repeated measures on GraphPad Prism 5(.)

Despite our efforts to standardize scale size during sampling, collected scales differed in size. Thus, to verify that scale size did not influence epithelium thickness and ensure that results only depended upon exposure to LAS, linear regressions were built on GraphPad Prism 5 for epithelium thickness versus scale length, and versus epithelium length.

Extremities are more variable than other regions due to the fact that sometimes the epithelium reduces in thickness suddenly and at other times, it does so gradually. Therefore, middle portions of the epithelium were generally considered more significant when interpreting results.

\subsection{Gill analysis}

Samples from the tank experiments were fixed with aqueous Bouin and $10 \%$ formaldehyde, dehydrated in ethyl alcohol and embedded in historesin Leica $\odot$. Histological slides were submitted to H.E. (Haematoxylin-Eosin) technique according to Paulete and Beçak (1976), and mounted in Entellan@. Morphological alterations were counted in 10 lamellae per section, for 8 sections per gill arch for each individual sampled ( $n=6$ per sampling, per group). Obtained values were submitted to Shapiro-Wilk's normality test and Kruskal-Wallis/Dunn test for comparison of means on GraphPad Prism 5․

\subsection{Water quality}

Chemical analyses were carried out according to the Standard Methods for the Examination of Water and Wastewater@ on the water analysis laboratory of UNESP, campus in Rio Claro (Laboratório de Análise de Águas - Departamento de Geologia Aplicada Instituto de Geociências e Ciências Exatas - UNESP, campus of Rio Claro, SP, Brazil). ICP-AES metal determination was performed for $\mathrm{Mg}, \mathrm{Ca}, \mathrm{Sr}, \mathrm{Ba}, \mathrm{Cr}(\mathrm{t}), \mathrm{Mn}, \mathrm{Fe}, \mathrm{Co}, \mathrm{Ni}, \mathrm{Cu}, \mathrm{Zn}, \mathrm{Cd}, \mathrm{Si}, \mathrm{P}(\mathrm{t})$ and $\mathrm{Pb}$. Ionic chromatography was performed to determine anions $\mathrm{F}^{-}, \mathrm{Cl}^{-}, \mathrm{NO}_{2}$, $\mathrm{NO}_{3}, \mathrm{PO}_{4}, \mathrm{SO}_{4}, \mathrm{ClO}_{2}^{-}$, acetate, oxalate and cations $\mathrm{Li}, \mathrm{Na}, \mathrm{NH}_{4}$ and $\mathrm{K}$.
Conductivity, $\mathrm{pH}$, total alkalinity and carbonates were determined by potentiometric titration. Samples for water quality were collected at the beginning of experiments.

Liquid chromatography was performed to determine real LAS concentration using an Agilent Technologies 1200 series HPLC in collaboration with a private company (Global Análise \& Consultoria@ - São Carlos, SP - Brazil). Samples for LAS determination were taken before every sampling campaign, at days 14, 21 and 30.

\section{Results}

\subsection{Epithelium thickness}

Epithelium thickness only increased in $0.36 \mathrm{mg} / \mathrm{L}$ of LAS at the beginning of tank experiments for most epithelial regions. After 21 days of experiment, the epithelium thickened in both surfactant concentrations and remained thicker than control groups until the end. Statistical comparisons pointed out significant differences between LAS groups only at 14 days, one group showed significant thickening and the other did not.

In aquarium experiments, epithelium thickness decreased in groups exposed to $0.36 \mathrm{mg} / \mathrm{L}$ only after 14 days and remained similar to the observed in control groups during the rest of the experiment (Fig. 2A). Exposure to $3.6 \mathrm{mg} / \mathrm{L}$ of LAS caused epithelial thinning in most sampling periods. Comparisons between both surfactant-exposed groups differed significantly, epithelium thickness significantly varied in one LAS concentration and did not on the other.

Linear regressions did not point out a relationship between scale length and epithelial thickness or epithelium length. In all cases, the data clustered (Supplementary material).

\subsection{Mucous cells}

Mucous cells were identified as magenta markings, at times showing a single cell and at others, showing pockets formed by secretion coming from several different cells (Fig. 3A).

In tank experiments, mucous cells increased in number after 21 days of exposure in both LAS concentrations and was significantly higher in the $3.6 \mathrm{mg} / \mathrm{L}$ group (Fig. 2B). After 30 days, fish exposed to $3.6 \mathrm{mg} / \mathrm{L}$ continued to show increased number of mucous cells, but fish exposed to $0.36 \mathrm{mg} / \mathrm{L}$ did not. Control groups showed increased number of mucous cells compared to previous sampling periods, which may have biased results. Responses differed statistically between LAS concentrations throughout the experiments $(p<0.05)$.

In aquarium experiments, mucous cell number increased at 14 days in the $0.36 \mathrm{mg} / \mathrm{L}$ concentration of LAS (Fig. 2B). Mucous cell number decreased in $3.6 \mathrm{mg} / \mathrm{L}$ of LAS from the beginning of experiments and remained low until the end. Responses differed statistically between LAS concentrations after 21 and 30 days of exposure, as one group responded to the contaminant and the other did not.

\subsection{Club cells}

Club cells were identified as large, homogeneous cells, weakly reactive to eosin, with eccentric nucleus (Fig. 3B). Club cell number varied significantly at 14 days of tank experiments and with a very small numerical difference from $3.6 \mathrm{mg} / \mathrm{L}$ to control. In aquarium experiments club cell number increased significantly for groups in $3.6 \mathrm{mg} / \mathrm{L}$ between all sampling periods, and with a much larger difference in number when compared to the control group (Fig. 2B). 


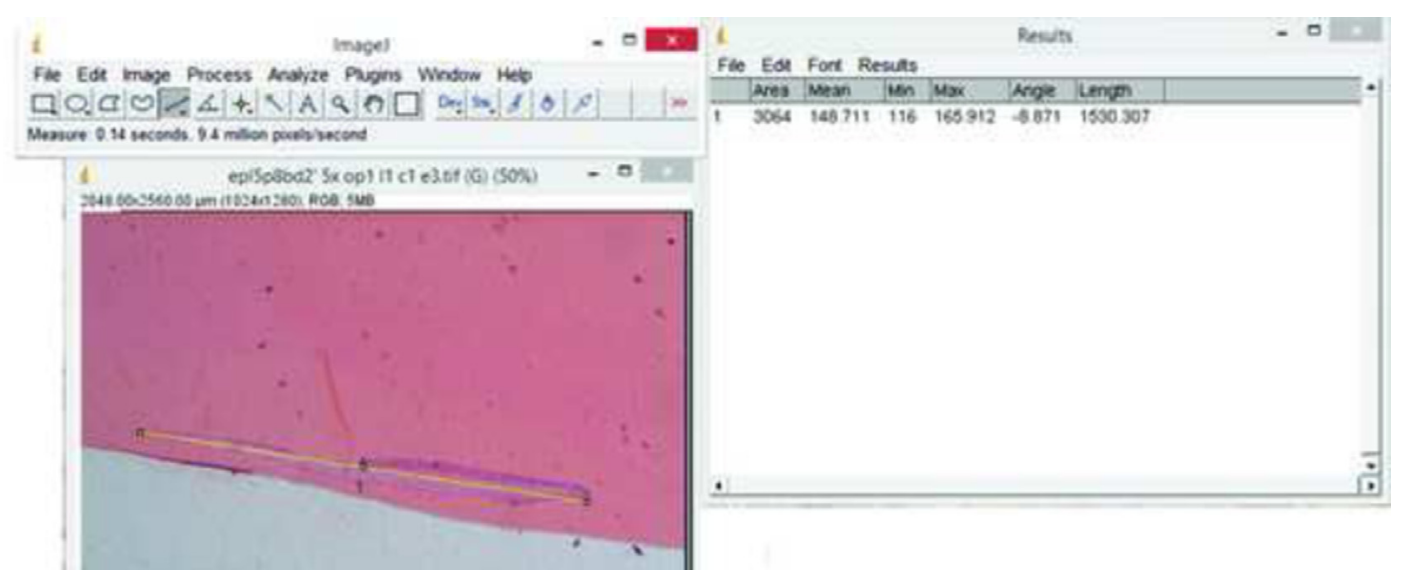

(A)
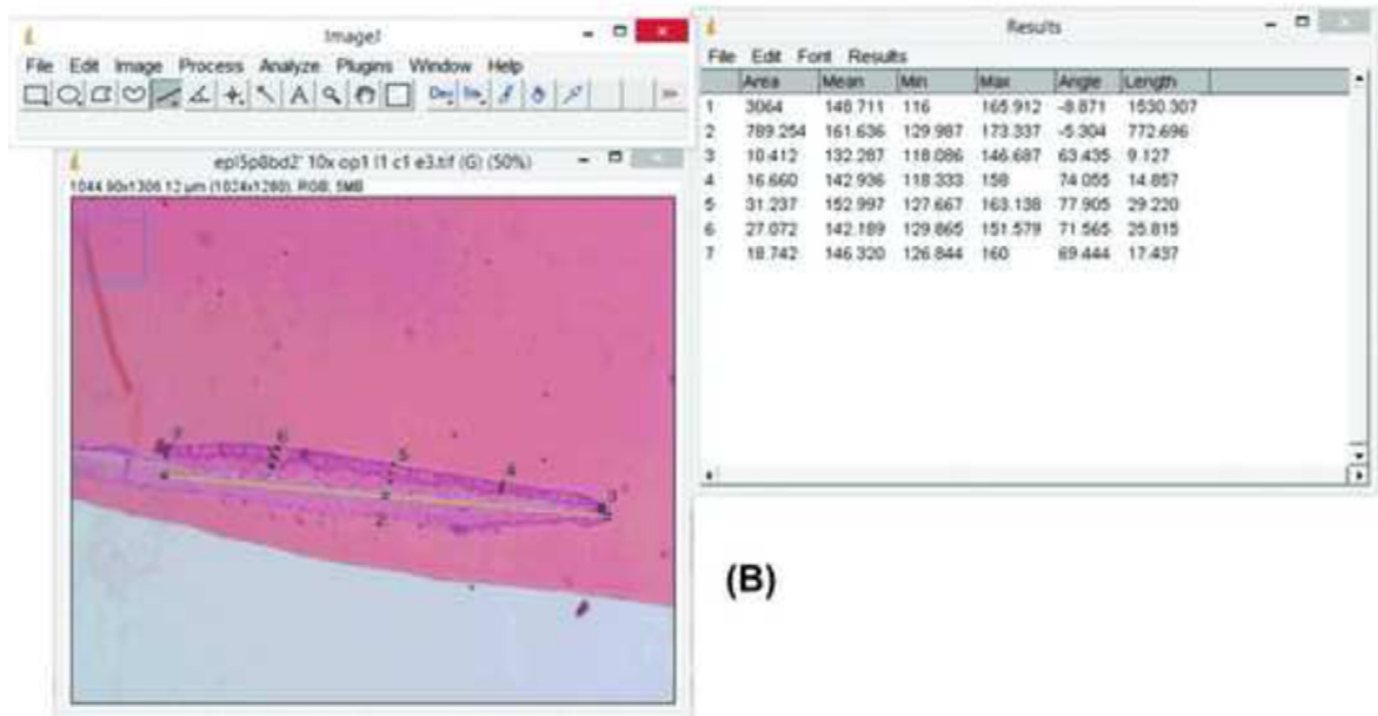

(B)

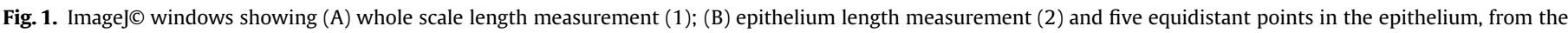

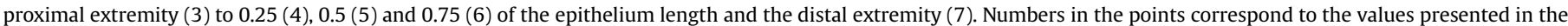
window named 'Results'.

\subsection{Gill analysis}

Exposure to LAS caused five types of structural changes on the gills: hypertrophy of pillar cells, hyperplasia of the secondary lamellae and of the primary filament, lamellar fusion, and aneurisms. The data shows that initial exposure to LAS caused mainly hypertrophy and hyperplasia, that were later substituted by lamellar fusion and aneurisms as the experiment progressed.

Alterations such as hyperplasia and hypertrophy increased significantly at 14 days of experiments for both experimental groups. Such increase did not statistically differ between both LAS concentrations during the entire experiment. Towards the end of experiments, it regressed with sporadic deviations (Fig. 2C).

Lamellar fusion increased in number at 14 days and was significantly higher in groups exposed to $3.6 \mathrm{mg} / \mathrm{L}$ of surfactant (Fig. 2C). After 21 days it decreased for $0.36 \mathrm{mg} / \mathrm{L}$ groups, response statistically differed between LAS exposed groups $(p<0.05)$.

Aneurism occurrence increased for $0.36 \mathrm{mg} / \mathrm{L}$ of LAS, with experimental groups differing in response $(p<0.05)$ at 14 days. After 21 days aneurisms increased in number in both LAS concentrations until the end and did not statistically differ between experimental groups (Fig. 2C).

\subsection{Water quality}

No physical-chemical parameters in the water analysis presented values above what is set by the brazilian Ministry of the Environment for freshwater quality (Resolution 357 - Conama). Although some parameters/elements were different between groups: $\mathrm{SO}_{4}^{2-}$ was elevated in units with $0.36 \mathrm{mg} / \mathrm{L}$ of LAS, while aluminium content was higher in both LAS concentrations. Their levels did not exceed the standard set by the government. The concentration of the $\mathrm{Cl}^{-}$ion was elevated in control samples compared to other groups, but it was also below the standard for freshwater quality. Since our containers were pumped during the whole experimental time, it can be assumed that chlorine levels dropped over time. A complete report for water quality can be found in the study of Alves (2015).

\section{Discussion}

The relevance of a lesion depends upon its pathological importance, e.g. the manner in which it affects the function of an organ and the survivability of an animal (Bernet et al., 1999). Such a statement is true for all histopathological alterations and 
(A)

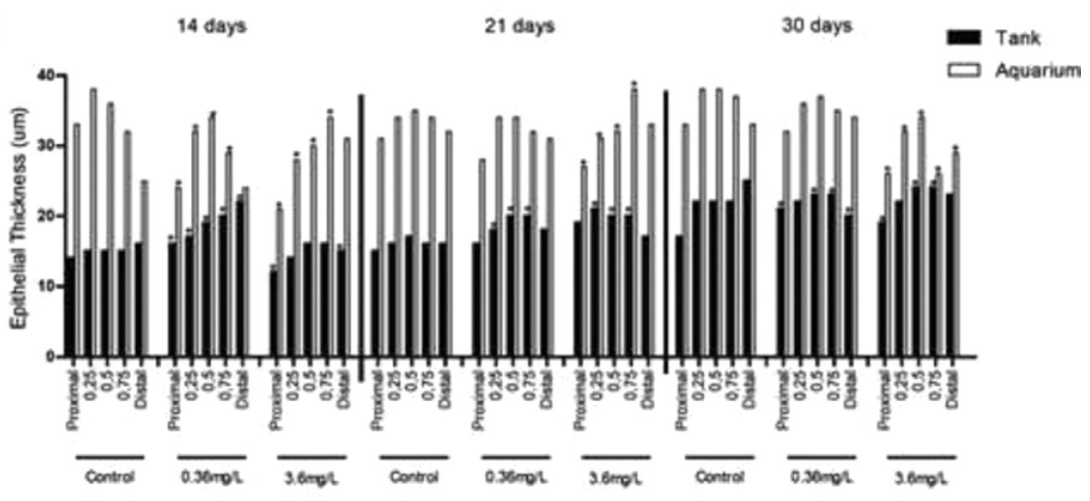

(B)

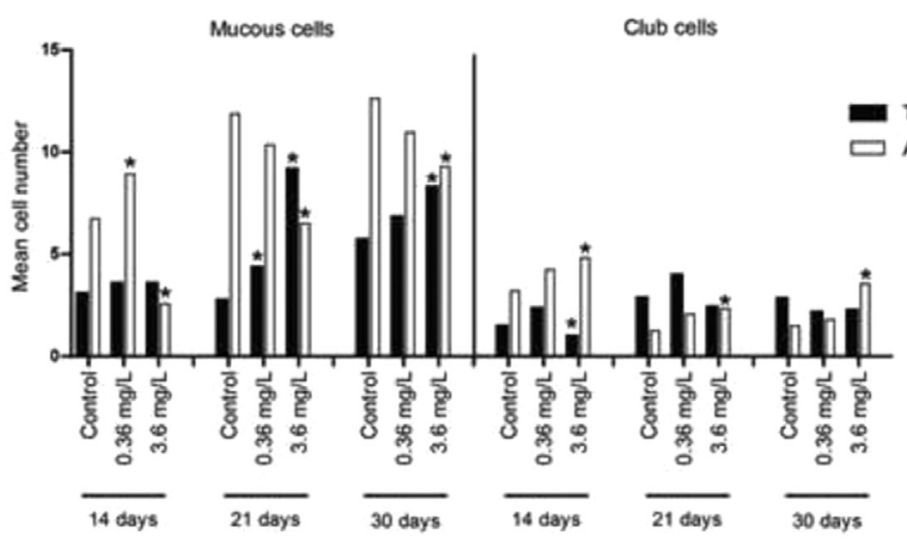

(C)

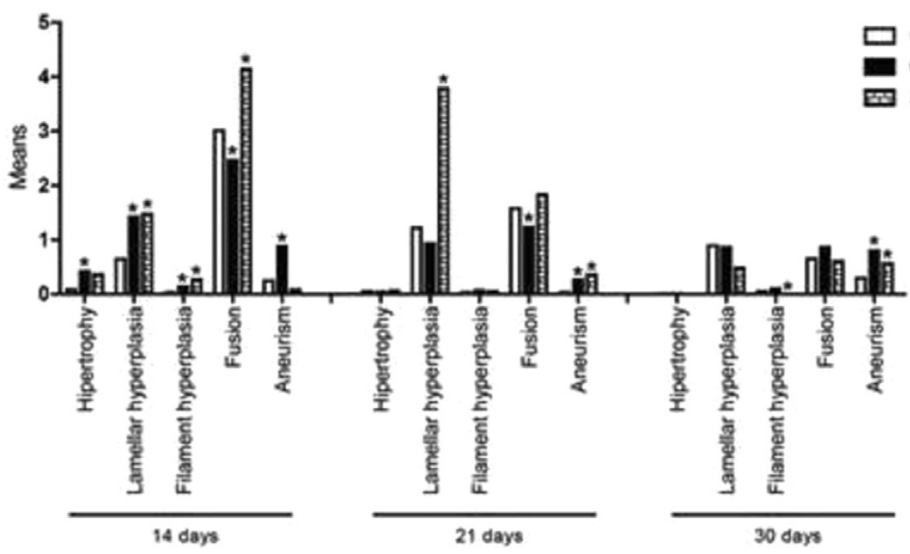



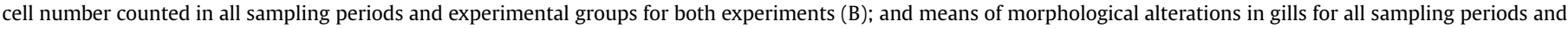
experimental groups. The asterisks indicate statistical difference with $p<0.05$ for comparisons of the respective group with the control.

provides a link between what was observed in the scale epithelium and the gills.

Hypertrophy and hyperplasia are classified as minimally to moderately important, as they are reversible, and progressive, and because they lead to increased cell and tissue activity (Bernet et al., 1999). These types of changes reduce interlamellar space and increase water/blood distance in fish, creating a barrier against the entry of contaminants (Camargo and Martinez, 2007; Paulino et al., 2012). This may explain why those alterations were found in gills at the beginning of experimentation and regressed after the fish habituated to surfactant concentrations or developed more severe lesions.

The same can be said for morphological changes observed in the scale epithelium. Hyperplasia can again be considered an adaptive or compensatory response to avoid contact with toxicants and was triggered right at the beginning of tank and aquarium experiments because it is a mild, reversible alteration (Bernet et al., 1999). Effects worsened with prolonged exposure to LAS in tanks, leading to epithelial thinning, in agreement with literature, that affirms that epithelial thickness increases with exposure to low doses and decreases with higher, critical concentrations (Kilamade and Mothersill, 2000). Although, exposure to higher concentrations of LAS may have caused resistance in aquariums instead of epithelial thinning. Resistance in this case would mean the regression of adaptive changes without posterior development of lesions.

The trend for mucous and club cell production was also of more severe effects only with the $3.6 \mathrm{mg} / \mathrm{L}$ exposure. Exposure to 


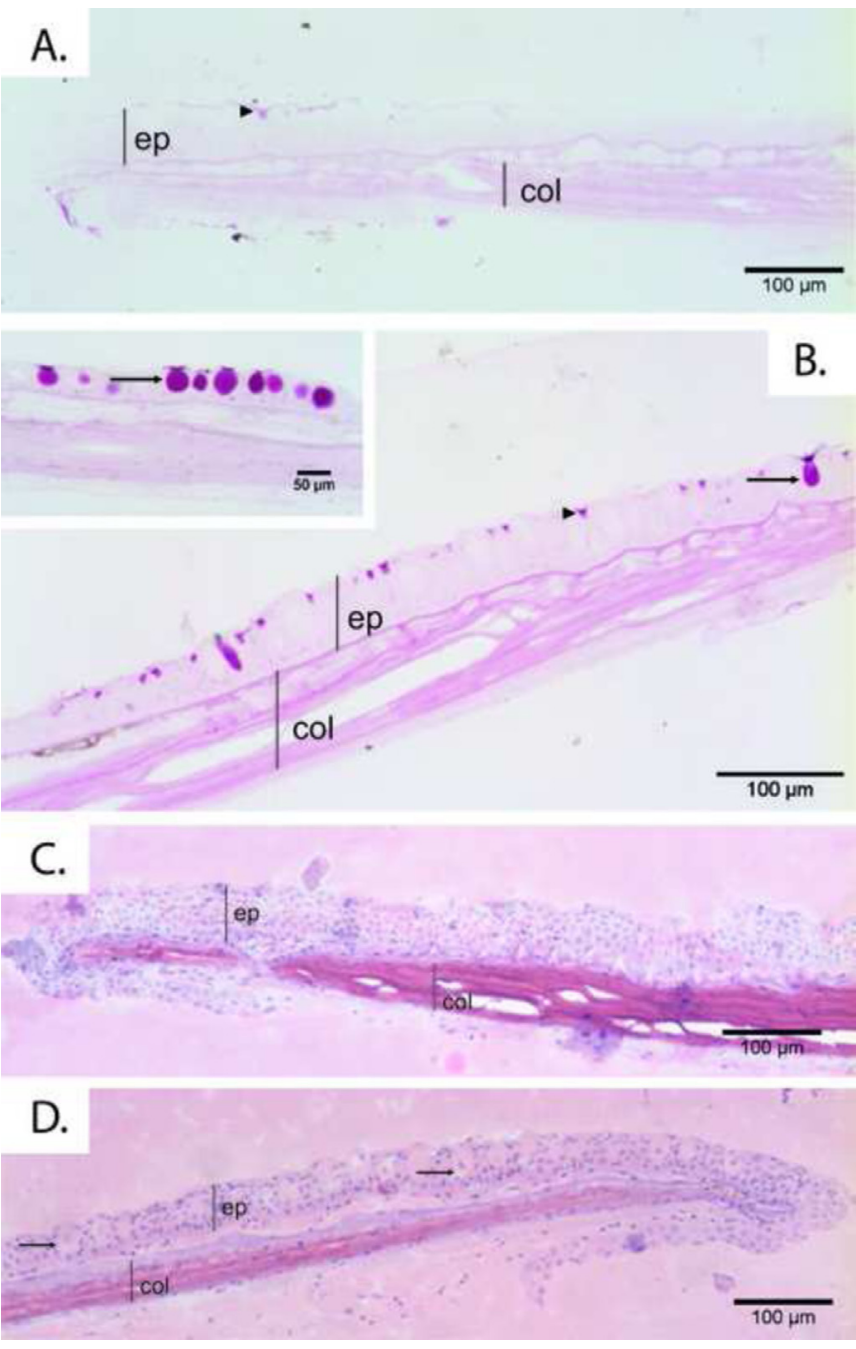

Fig. 3. Periodic Acid-Schiff slides (A and $B$ ) and Haematoxylin-Eosin slides ( $C$ and D) of scales from control group (A and C) and a group exposed to $3.6 \mathrm{mg} / \mathrm{L}$ of LAS (B and D). Arrow heads in A and B indicate mucous cell markings in epithelium (ep) and arrows in $A$ and $B$ show markings of pockets formed by secretion coming from several different cells. In $C$ and $D$, arrows indicate club cells, identified as larger, homogeneous cells. col: collagen.

$0.36 \mathrm{mg} / \mathrm{L}$ did not impact the number of club cells, and mucous cell count varied only in the initial sampling periods in both types of experiments. Exposure to high concentrations $(3.6 \mathrm{mg} / \mathrm{L})$ caused an increase in club cell and mucous cell production during the whole aquarium experiment.

Severe effects in gills evolved directly from the adaptive changes in the beginning of experiments. Uncontrolled hyperplasia can lead to complete or partial lamellar fusion, reducing respiratory surface (Rajbanshi and Gupta, 1988) and further increasing water/blood distance (Mallatt, 1985), which explains lamellar fusion occurrence at the beginning of experiments, accompanying hyperplasia and hypertrophy.

Fusion of lamellae is not an extremely grave effect, but such an alteration in the gill surface can involve electrolytic imbalance phenomenoma (Cerqueira and Fernandes, 2002) and alkyl benzenes themselves as well as other types of surfactants impact membrane penetration (Konnecker et al., 2011). The consequence is ionic imbalance that induces hypoxia and other severe pathological states such as increased blood flow (Zhu et al., 2002), and consequent pillar cell rupture, a known cause of aneurysms (Martinez et al., 2004). This is likely the reason for high incidence of aneurysms observed after prolonged LAS exposure.

Severe effects after prolonged exposure in the scale epithelium were of a different nature. Epithelial thinning can be a consequence of immunosuppression caused by prolonged exposure to contaminants (Tort, 2011) such as LAS. This alteration was observed throughout aquarium experiments in the higher concentration, indicating serious effects of LAS and such effects could worsen with time, as immunosuppression can be related to grave cases of skin infection, developing into ulceration, even as a result of stress by confinement (Noga et al., 1998), if the fish does not develop resistance.

Higher doses of surfactant also provoked increased mucous cell production in tank experiments, but decreased cell number was observed in aquariums. Garg and Mittal (1993) explain decreased mucous production with functional depletion states between resting phases and intense secretory phases, in cases where response is exaggerated and the cells need a period to regain their ability to synthetize. In our aquarium experiments, mucous production was already high in control groups, so a decrease in mucous cells number in LAS exposed groups may just represent an exhaustion state after even higher mucous production rates were induced by the surfactant, or a depletion in the ability to properly regulate mucous production as a compensatory response to the toxicant agent. Other than that mucous production can be affected by immunosuppressive events, since mucous plays a role in immune responses (Roumbout et al., 1993; Wendelaar-Bonga, 1997) and immunosuppression can occur in cases of prolonged stress (Tort, 2011).

Mucous has been associated with a large spectrum of skin functions (Bernet et al., 1999; Coello and Khan, 1995; Coello and Khan, 1996; Zaccone et al., 2001), therefore these responses that affect mucous production can lead to effects on physical, chemical and immune protection regulated and compromised through mucous production and its response to surfactant exposure at different levels.

Club cells responded solely to the higher dose of surfactant. They are multifunction epidermal secretory cells found in several orders of fish, that have been thought to produce alarm substances, anti-pathogen agents, regulatory factors and respond to stress agents (Brown, 2003; Chivers et al., 2007; Halbgewachs et al., 2009; Iger et al., 1994; McPherson et al., 2004; Pfeiffer, 1977; Smith, 1992; Zaccone et al., 2001).

Our tank experiments showed a significant decrease in club cell number with initial exposure to a higher concentration of LAS. There is evidence that club cells participate in immune responses against pathogens that injure the epidermis (Halbgewachs et al., 2009; Zaccone et al., 2001), so immunosuppression induced by contaminant exposure at higher levels could have caused such a decrease, as was demonstrated in gills and mucous production in the scale. Such a depletion in cell number reflects a redirection of energy away from non-essential functions such as club cell production (Halbgewachs et al., 2009).

Another hypothesis would recap a theory regarding fish blood cells. Club cells could act the same as thrombocytes, which increased in number when the fish were first exposed to a contaminant and decrease, not by suppression, but because they are substituted by more specific immune cells (Pereira et al., 2012).

On the other hand, aquariums exhibited a standard spectrum of alterations, seeing as other authors show increase in club cell number as a response to contaminants, mechanical stress or pathogens (Chivers et al., 2007; Halbgewachs et al., 2009; Rajan and Banerjee, 1991), and their migration to the epithelial surface (Iger et al., 1994; Rajan and Banerjee, 1991) to facilitate content release (Pfeiffer, 1977). Although an exact causal relationship between epidermal injury and club cell production has not yet been found, some authors believe mechanical damage to be a part of what 
triggers club cell production, but other chemical cues from causal agents should be necessary for there to be adaptive changes in cellular chemistry (Chivers et al., 2007). Other than that, immunosuppression mechanisms may also be involved in processes of pathogen inhibition (Chivers et al., 2007).

In general, alterations in gills and scales were comparable, aquarium experiments showed the worst lesions only after a longer exposure time in scales and both in tank and aquarium experiments, first contact with the surfactant lead to adaptive responses that later regressed, as was observed in gills.

All responses and lesions cited were also observed by other authors (Camargo and Martinez, 2007; Cerqueira and Fernandes, 2002; Mallatt, 1985; Paulino et al., 2012; Simonato et al., 2008) and what was observed in our experiments is not an extremely severe case but can develop into much more aggressive contamination states if pollutants persist in the environment (Mallatt, 1985; Reddy and Rawat, 2013).

All these alterations are also not contaminant-specific (Elahee and Bhagwant, 2007; Mallatt, 1985; Troncoso and Cazenave., 2012) and different patterns of reaction can be observed depending on the nature of the contaminant, its concentration, period of exposure and target specie (Reddy and Rawat, 2013).

Variation in different types of experiments could reflect a variety of factors, from sample size to additional stress factors such as handling of fish and acclimatization periods, which can affect results even in behavior studies (Moreira et al., 2010). As all parameters were standardized to what is known to work in literature, there is one last hypothesis left - stress by confinement in aquarium experiments. Since our target specie is a river species that swims in shoals, isolating individuals seems to have raised stress levels considerably and specimens kept swimming erratically in the confined space. Despite our effort to use aquariums bigger than what is practiced for individual testing on literature (Moreira et al., 2010), keeping fish isolated affected significantly their response to contaminants and raised stress levels.

Other than that, LAS and other alkybenzenes break down into different isomers, each with different degrees of ecotoxicity (Hera, 2009; Konnecker et al., 2011) and morphological effects depend not only upon that, but on water quality (Konnecker et al., 2011; Verge et al., 2001) because elements such as metals and ions can interact with other contaminants, causing synergetic or additive effects that potentiate toxic action (Lin et al., 2005; Lorris and Shane, 1993).

Acute and chronic toxicity for LAS and other alkylbenzenes are well documented. Values of tolerance range from $4.6 \mathrm{mg} / \mathrm{L}$ to $9.2 \mathrm{mg} / \mathrm{L}$ in 7 to 8 days of exposure and $0.35 \mathrm{mg} / \mathrm{L}$ to $5.5 \mathrm{mg} / \mathrm{L}$ in 14 to 35 days of exposure to alkylbenzenes (Konnecker et al., 2011). Although values usually range from 3 to $4 \mathrm{mg} / \mathrm{L}$ in acute exposure and $0.3-1 \mathrm{mg} / \mathrm{L}$ in chronic exposure in LAS studies (Hera, 2009). With that said, concentrations tested and sampling periods are comparable to what is found in literature, and provoked ecotoxicological effects.

\section{Conclusions}

Results show histopathological effects on gills in both LAS concentrations in all experimental periods, with more severe effects on higher concentrations. The scale epithelium, though more variable in results, also responded to LAS, only more consistently in the higher dose. The technique needs further studies and refinement, efforts to standardize results and define sensitivity compared to traditional techniques, but it shows great potential as a method of environmental assessment and the advantage of being a quick, not expensive and non-invasive sampling technique.

\section{Acknowledgments}

We thank Fundação de Amparo à Pesquisa do Estado de São Paulo (FAPESP) for funding the master project (Process no. 2012/ 08446-5) and the research project (Process no. 2012/03414-8) of which this paper is a part. We also thank the pisciculture Piscicultura Polettini for providing specimens for study and Ph.D. Henrique Hespanhol Tozzi and MSc Renata Mamede da Silva Alves for revising the manuscript.

\section{Appendix A. Supporting information}

Supplementary data associated with this article can be found in the online version at http://dx.doi.org/10.1016/j.ecoenv.2016.03.010.

\section{References}

Abdullah, M.I., Banks, J.W., Miles, D.L., O'grady, K.T., 1976. Environmental dependence of manganese and zinc in the scales of atlantic salmon, Salmo salar (L) and brown trout Salmo truta (L). Freshw. Biol. 6 (2), 161-166.

Alves, R.M.S., 2015. Efeito do ambiente alterado no epitélio da escama, nas brânquias e na alimentação de Prochilodus lineatus (Masters dissertation, Universidade Estadual Paulista "Júlio de Mesquita Filho" campus of Rio Claro), Retrieved from: http://repositorio.unesp.br/handle/11449/123722.

Anderson, S., Sadinski, W., Shugart, L., Brussard, P., Depledge, M., Ford, T. Hose, J., Stegeman, J., Suk, W., Wirgin, I., Wogan, G., 1994. Genetic and molecular ecotoxicology: a research framework. Environ. Health Perspect. 102 (12), 3-8.

Bernet, D., Schmidt, H., Meier, W., Burkhardt-Holm, P., Whali, T., 1999. Histopathology in fish: proposal for a protocol to assess aquatic pollution. J. Fish Dis. 22, 25-34.

Brown, E.G., 2003. Learning about danger: chemical alarm cues and local risk assessment in prey fishes. Fish Fish. 4, 227-234.

Burguer, J., Jeitner, C., Donio, M., Pittfield, T., Gochfeld, M., 2013. Mercury and selenium levels, and selenium: mercury molar rations of brain, muscle and other tissues in bluefish (Pomato mussaltatrix) from New Jersey, USA. Sci. Total Environ. 443, 278-286.

Camargo, M.M.P., Martinez, C.B.R., 2007. Histopathology of gills, kidney and liver of a Neotropical fish caged in an urban stream. Neotrop. Ichthyol. 3 (5), 327-336.

Cerqueira, C.C.C., Fernandes, M.N., 2002. Gill tissue recovery after copper exposure and blood parameter responses in the tropical fish Prochilodus scrofa. Ecotoxicol. Environ. Saf. 52, 83-91.

Chivers, D.P., Wisenden, B.D., Hindman, C.J., Michalak, T.A., Kusch, R.C., Kaminskyj, G.W., Jack, K.L., Ferrari, M.C.O., Pollock, R.J., Halbgewachs, C.F., Pollock, M.S. Alemadi, S., James, C.T., Savaloja, R.K., Goater, C.O., Corwin, A., Mirza, R.S., Kiesecker, J.M., Brown, G.E., Adrian, J.R., Krone, J.C., blaustein, P.H., Mathis, A.R., 2007. Epidermal "alarm substance" cells of fishes maintained by non-alarm functions: Possible defence against pathogens, parasites and UVB radiation. Proc.: Biol. Sci. 274 (1625), 2611-2619.

Coello, W.F., Khan, A.Q., 1996. Protection against heavy metal toxicity by mucus and scales in fish. Arch. Environ. Contam. Toxicol. 30, 319-326.

Dowling, K., Mothersill, C., 2001. The further development of rainbow trout primary epithelial cell cultures as a diagnostic tool in ecotoxicology risk assessment. Aquat. Toxicol. 53, 279-289.

Dua, A., Gupta, N., 2005. Mercury toxicology as assessed through fish scales. Bull. Environ. Contam. Toxicol. 74, 1105-1110.

Elahee, K.B., Bhagwant, S., 2007. Hematological and gill histopathological parameters of three tropical fish species from a polluted lagoon on the west coast of Mauritius 381-371. Ecotoxicol. Environ. Saf. 68, 361-371.

Garg, T.K., Mittal, A.K., 1993. Observations on the function of mucous cells in the epidermis of the cat-fish Clarias batrachus exposed do sodium dodecyl sulfate. Biomed. Environ. Sci. 6, 119-133.

Halbgewachs, C.F., Marchant, T.A., Kusch, R.C., Chivers, D.P., 2009. Epidermal club cells and the innate immune system of minnows. Biol. J. Linn. Soc. 38, 891-897.

Heltsley, R.M., Cope, W.G., Shea, G., Bringolf, R.B., 2005. Assessing organic contaminants in fish: comparison of a nonlethal tissue sampling technique to mobile and stationary passive sampling devices. Environ. Sci. Technol. 39 (19), $7601-7608$

Hera, 2009. LAS human and environmental risk assessment on ingredients of European household cleaning products: linear alkilbenzene sulphonates, LAS. CAS no. 68411-30-3, version 4.0. 〈http://www.heraproject.com/riskassessment. cfm〉.

Iger, Y., Lock, A.C., Van Der Meji, J.C.A., Wendelaar Bonga, S.E., 1994. Effects of waterborne cadmium on the skin of the common carp (Carpio carpio). Arch. Environ. Contam. Toxicol. 26, 342-350.

Kilemade, M., Mothersill, C., 2000. An in vitro assessment of the toxicity of 2,4dichloroaniline using rainbow trout primary epidermal cell cultures. Environ. Toxicol. Chem. 19 (8), 2093-2099.

Konnecker, G., Regelmann, J., Belanger, S., Gamon, K., Sedlak, R., 2011. 
Environmental properties and aquatic hazard assessment of anionic surfactants: physico-chemical, environmental fate and ecotoxicity properties. Ecotoxicol. Environ. Saf. 74, 1445-1460.

Lin, Z., Ping, Z., Kong, D., Yin, K., Cai, Z., 2005. The ratios of individual chemicals in a mixture determine the degree of joint effect: the climax hypothesis. Arch. Environ. Contam. Toxicol. 49, 1-8.

Lorris, G.C., Shane, B.S., 1993. Basic Environmental Toxicology, 1st edition. CRC Press, London, p. 640.

Mallatt, J., 1985. Fish gill structural changes induced by toxicants and others irritants: a statistical review. Can. J. Fish Aquat. Sci. 42, 630-648.

Martinez, C.B.R., Nagae, M.Y., Zaia, D.A.M., 2004. Acute morphological and physiological effects of lead in the neotropical fish Prochilodus lineatus. Braz. J. Biol. 64, 797-807.

Mccart, P., 1967. Scale regeneration in the blue spot goby, Coryphopterus nicholsi. J. Fish Res. Board Can. 24 (2), 433-434.

Mcpherson, T.D., Mirza, R.S., Pyle, G.G., 2004. Responses of wild fishes to alarm chemicals in pristine and metal-contaminated lakes 964-700. Can. J. Zool. 82 (5), 694-700.

Meschiatti, A.J., Arcifa, M.S., 2009. A review on the fish fauna of Mogi-Guaçu River basin: a century of studies. Acta Limnol. Bras. 21 (1), 135-159.

Moreira, S.M., Moreira-Santos, M., Rendón-Von Osten, J., Da Silva, E.M., Ribeiro, R., Guilhermino, L., Soares, A.M.V.O.L.M., 2010. Ecotoxicological tools for the tropics: sublethal assays with fish to evaluate edge-of-field pesticide runoff toxicity. Ecotoxicol. Environ. Saf. 73, 893-899.

Mungray, A.K., Kumar, P., 2009. Fate of linear alkylbenzene sulfonates in the environment: a review. Int. Biodeterior. Biodegrad. 63, 981-987.

Noga, E.J., Botts, S., Yang, M.S., Avtalion, R., 1998. Acute stress induces skin ulceration in striped bass and hybrid bass (Morone). Vet. Pathol. 35 (2), 102-107.

Palermo, F.F., Risso, W.E., Simonato, J.D., Martinez, C.B.R., 2015. Bioaccumulation of nickel and its biochemical and genotoxic effects on juveniles of the neotropical fish Prochilodus lineatus. Ecotoxicol. Environ. Saf. 116, 19-28.

Paulete, J., Beçak, W., 1976. Técnicas de Citologia e Histologia. 2. Livros Técnicos e Científicos, São Paulo, p. 469.

Paulino, M.G., Souza, N.E.S., Fernandes, M.N., 2012. Subchronic exposure to atrazine induces biochemical and histopathological changes in the gills of a neotropical fish, Prochilodus lineatus. Ecotoxicol. Environ. Saf. 80, 6-13.

Pereira, B.F., Alves, R.M.S., Pitol, D.L., Senhorini, J.A., Alcântara-Rocha, R.C.G., Caetano, F.H., 2012. Effects of exposition to polluted environments on blood cells of the fish Prochilodus lineatus. Microsc. Res. Tech. 75, 571-575.

Pereira, B.F., Alves, R.M.S., Alves, A.L., Senhorini, J.A., Rocha, R.C.G.A., Hakime, S.P., Pitol, D.L., Caetano, F.H., 2014. Effects of biodegradable detergents in morphological parameters of liver in two neotropical fish species (Prochilodus lineatus and Astyanax altiparanae). Microsc. Res. 2, 39-49.

Pfeiffer, W., 1977. Distribution of frigth reaction and alarm substance cells in fishes. Copeia 1977 (4), 653-665.

Pretti, C., Chiappec, C., Pieraccini, D., Gregori, M., Abramo, F., Gianfranca, M., Intorre L., 2008. Acute toxicity fo ionic liquids to the zebrafish (Danio rerio). J. R. Soc. Chem. 8, 238-240.

Rajan, M.T., Banerjee, T.K., 1991. Histopathological changes induced by acute toxicity of mercuric chloride on the epidermis of freschwater catfish - Heteropneustes fossilis (Bloch). Ecotoxicol. Environ. Saf. 22, 139-152.

Rajbanshi, V.O.L.K., Gupta, A.K., 1988. Alterations in the architecture of the gill surface produced by water-borne copper in Heteropneustes fossilis (Bloch). Acta Hydrochim. Hydrobiol. 16 (3), 325-331.

Reddy, P.B., Rawat, S.S., 2013. Assessment of aquatic pollution using histopathology in fish as a protocol. Int. Res. J. Environ. Sci. 2 (2), 79-82.

Reis, R.E., Kullander, S.O., Ferraris, C.J., 2003. Check list of the freshwater fishes of South and Central America. Pontificia Universidade Católica do Rio Grande do Sul. Museu de Ciências e Tecnologia: EDIPUCRS, Porto Alegre.

Roumbout, J.H.W.M., Tarverne, N., Van De Kamp, M., Taverne-Thiele, A.J., 1993. Differences in mucus and serum immunoglobulin of carp (Cyprinus carpio L.). Dev. Comp. Immunol. 17, 309-317.

Simonato, J.D., Guedes, C.L.B., Martinez, C.B.R., 2008. Biochemical, physiological, and histological changes in the neotropical fish Prochilodus lineatus exposed to diesel oil. Ecotoxicol. Environ. Saf. 69, 112-120.

Schwaiger, J., Wanke, R., Adam, S., Pawert, M., Honnen, W., Triebskorn, R., 1997. The use of histopathological indicators to evaluate contaminant-relevant stress in fish. J. Aquat. Ecosyst. Stress. Recov. 6, 75-86.

Smith, R.J.F., 1992. Alarm signals in fishes. Rev. Fish Biol. Fish. 2, 33-63.

Tort, L., 2011. Stress and immune modulation in fish. Dev. Comp. Immunol. 35, 1366-1375.

Troncoso, I.C., Cazenave, J., 2012. Histopathological changes in the gills and liver of Prochilodus lineatus from the Salado River basin (Santa Fe, Argentina). Fish Physiol. Biochem. 38, 693-702.

Verge, C., Moreno, A., Bravo, J., Berna, J.L., 2001. Influence of water hardness on the bioavailability and toxicity of linear alkylbenzene sulphonate (LAS). Chemosphere 44, 1749-1757.

Wendelaar-Bonga, S.E., 1997. The stress response in fish. Physiol. Rev. 77 (3), 592-625.

Zaccone, G., Kapoor, B.G., Fasulo, S., Ainis, L., 2001. Structural, histochemical and functional aspects of the epidermis of fishes. Adv. Mar. Biol. 40, 255-348.

Zhu, H., Jackson, T., Bunn, H.F., 2002. Detecting and responding to hypoxia. Nephrol. Dial. Transplant. 17, 3-7. 